\title{
Stresul oxidativ în hepatitele cronice la copil
}

\author{
Alice N. Azoicăi, Bogdan A. Stana \\ Clinica II Pediatrie, Spitalul Clinic de Urgenţă pentru Copii „Sf. Maria“, \\ Universitatea de Medicină şi Farmacie „Gr. T. Popa“, Iaşi, România
}

\begin{abstract}
REZUMAT
Stresul oxidativ reduce eficacitatea mecanismelor efectorii ale răspunsului imun, făcând celulele mai susceptibile la apoptoză. La nivelul celulelor limfoide, radicalii liberi interferă cu răspunsul la tratamentul antiviral, determinând rezistența la terapie şi favorizând cronicizarea infecției. Unul dintre factorii responsabili de stresul oxidativ în infecția cronică cu hepatită virală B este producția crescută de citokine proinflamatorii. Virusul hepatitei $\mathrm{C}$ poate induce direct stres oxidativ în hepatocite; expresia genelor core ale VHC a fost asociată cu creşterea speciilor reactive de oxigen (SRO), scăderea intracelulară şi/sau mitocondrială a conținutului de glutation (GSH) şi creşterea nivelului tioredoxinei oxidate şi a produşilor peroxidării lipidice. Nivelul crescut al malonildialdehidei (MDA) în serul pacienților cu hepatocarcinom, ca produs al stresului oxidativ, semnalează fidelitatea acestui marker în cuantificarea severității leziunii hepatice.

Reducerea stresului oxidativ se poate face utilizând medicația antioxidantă (hepatoprotectoare, acid ursodeoxicolic şi vitaminele A, C, E), acest demers reprezentând un beneficiu important pentru pacient, după cum rezultă şi din studiile întreprinse.
\end{abstract}

Cuvinte cheie: stres oxidativ, hepatită cronică, copil

Stresul oxidativ reduce eficacitatea mecanismelor efectorii ale răspunsului imun, făcând celulele mai susceptibile la apoptoză. La nivelul celulelor limfoide, radicalii liberi interferă cu răspunsul la tratamentul antiviral, determinând rezistență la terapie şi favorizând cronicizarea infecției.

Virusurile hepatitice B şi C intervin în amplificarea stresului oxidativ, în infecția cronică, prin mecanisme diferite. Unul dintre factorii responsabili de stresul oxidativ în infecția cronică cu virus B este producția crescută de citokine proinflamatorii. La aceşti pacienţi s-au decelat niveluri crescute de $\mathrm{TNF} \alpha$, factor responsabil de creşterea ratei de producție a superoxizilor la nivel mitocondrial. De asemenea, la pacienți cu hepatită virală B cronică (VHB) s-au obiectivat scăderi ale activităţii glutationului (GST), direct proporțional cu rata de progresie spre hepatocarcinom. Frecvența mai mare a pacienților cu hepatită virală C (HVC) la care stresul oxidativ se manifestă pregnant, ducând la rezistență terapeutică poate fi explicată prin existența unor depozite celulare de fier mai bine reprezentate la aceşti pacienți, fierul servind ca substrat pentru activarea cascadei stresului oxidativ. (1)

\section{Mecanismele stresului oxidativ în infecția cu VHB}

Speciile reactive de oxigen şi produşii de peroxidare lipidică pot contribui atât la instalarea, cât şi la progresia fibrozei hepatice. În plus, stresul oxidativ afectează în mod direct ADN-ul viral, putând conduce la dezvoltarea carcinomului hepatocelular (HCC).

Cengiz et. al (2005) au evaluat statusul oxidativ folosind, în principal, măsurarea răspunsul antioxidant total (TAR) al subiecților cu HVB cronică sau ciroză. (2) Din aceleaşi probe de plasmă a fost măsurat şi nivelul total de peroxid. Raportul dintre totalul nivelului de peroxid şi valoarea TAR din plasmă a fost definit ca indice de stres oxidativ. Au fost incluşi în studiu un număr de 33 de bolnavi, 20 de bărbaţi şi 13 femei, cu vârsta medie de $39 \pm 12,8$ ani. Pacienții cu ciroză hepatică de origine HVB (în număr de 12) au fost 7 bărbați şi 5 femei, cu vârsta medie de 40,9 $\pm 11,6$ ani, iar lotul martor a cuprins 16 subiecți, 9 de sex masculin şi 7 de sex feminin, cu vârsta medie de 31,6 \pm 6 ani, fără suferință hepatică. Răspunsul TAR a fost semnificativ mai mic la pacienții cu ciroză hepatică față de grupul-control. Diferența dintre subiecții cu HVB cronică şi su- 
biecții cu ciroză hepatică, în ceea ce priveşte TAR nu a fost semnificativă din punct de vedere statistic. Nivelul total de peroxid plasmatic al subiecților cu VHB şi ciroză a fost semnificativ mai mare decât în grupul-control. Nu a existat o corelație semnificativă între valoarea TAR şi cea a TGP. Totuşi, la bolnavii cu hepatită cronică $\mathrm{B}$, nivelul TGP seric s-au corelat pozitiv cu nivelul total de peroxid. (2)

Leziunile tisulare dobândite prin stres oxidativ în hepatita virală cronică B sunt însoțite de o creştere semnificativă a nivelului plasmatic al citokinelor fibrogenice, TGF $\beta$, respectiv $\mathrm{TNF} \alpha$. In plus, speciile reactive de oxigen acumulate în cantități mari în țesuturile inflamate pot provoca leziuni în celulele-gazdă şi pot induce deteriorarea ADNului, cu apariția de noi mutații. Deteriorarea ADNului sub acțiunea stresului oxidativ joacă un rol important în dezvoltarea cirozei hepatice de etiologie VHB şi în progresia spre hepatocarcinom. $(2,3)$

Cuantificarea nivelului de aflatoxină B (AFB1), evaluarea stresului oxidativ şi modificarea biomarkerilor de replicare virală au evidențiat un nivel plasmatic al AFB1 semnificativ mai mare în cazul pacienților cu hepatocarcinom, comparativ cu cei care prezintă hepatită cronică de origine HVB fără degenerescență malignă. Rezultatele indică o contribuție semnificativă a infecției cu VHB la acțiunea stresului oxidativ într-o populație cu expunere la AFB1, care ar putea creşte în mod substanțial riscul evolutiv spre HCC. (3)

Mutanţii pre-S pot să influenţeze şi activitatea COX-2 prin modularea NFkB şi a p38 MAPK. Excesul de COX-2, detectat în multe tipuri de cancer, a fost legat de progresia bolii. Modelele experimentale (şoareci transgenici) care exprimă proteine pre$\mathrm{S}$ mutante au niveluri mai ridicate de COX-2 în mostrele tisulare recoltate din ficat şi rinichi. În mod similar, expresia crescută a COX-2 a fost observată în țesuturile umane recoltate de la indivizi cu HCC de origine HVB.

Hui-Ching Wang et al. au studiat efectul mutanților pre-S, stresul oxidativ la nivelul reticulului endoplasmatic (RE) şi evoluţia spre cronicizare, ciroză şi HCC la pacienții cu infecție VHB (4). Proteinele pre-S mutante sunt acumulate în ER şi induc semnale de stres către reticulul endoplasmatic (Fig.1). Utilizând o metodă colorimetrică dublumarcată cu imunofluorescență, autorii au observat aglomerări consistente de proteine pre-S mutante şi calregulină în RE, ceea ce sugerează că aceste proteine mutante, atât $\Delta \mathrm{S} 1$-LHBs, cât şi $\Delta \mathrm{S} 2$-LHBs, se acumulează la acest nivel. Mutanții pre-S pot induce ulterior semnale de stres, ceea ce duce către degenerescență celulară şi evoluție spre HCC. De ase- menea, proteinele pre-S induse de genele mutante pot induce instabilitate genomică prin stres oxidativ, producând deteriorarea $\mathrm{ADN}$-ului cu creşterea frecvenței de apariție a unor noi mutații.

Pentru a demonstra că pacienții cu VHB şi cu expresie crescută a proteinelor pre-S mutante comportă un risc mai mare de dezvoltare a HCC, autorii au întreprins un studiu cazuistic într-un grup de pacienți AgHBs pozitivi. S-au luat în studiu 68 de bărbați cu HCC nou diagnosticat şi 132 de subiecți în lotul martor cu infecție HVB fără HCC. Printre aceste cazuri, 14 bărbați cu HCC $(20,6 \%)$ şi 11 din lotul martor $(8,3 \%)$ au avut mutante detectabile de proteine pre-S în probele recoltate. Pe o perioadă de urmărire de 10 ani, pacienții care au dezvoltat mutante pre-S au avut un risc mai mare de a dezvolta HCC decât ceilalți (HI Yang şi CJ Chen, date nepublicate). Aceste date indică faptul că apariția mutanților de pre-S poate prezenta un risc ridicat de a dezvolta HCC la pacienții cu infecție cronică cu VHB.

Studiile acumulate susțin ipoteza conform căreia stresul oxidativ poate avea un rol critic în determinarea şi progresia leziunilor hepatice, fiind asociat cu severitatea bolii şi starea de replicare a virusului în infecția cu virus B. Astfel, se impune evaluarea posibilității unor linii terapeutice țintite pe această linie patogenică.

\section{Mecanismele stresului oxidativ în infecția cu VHC}

Aplicarea unor criterii de eligibilitate pentru tratamentul antiviral a incitat studierea rolului stresului oxidativ. (5) Mecanismele de acțiune prin care se produc aceste leziuni sunt:

- activarea NAD(P)H oxidazei din celulele Kupffer şi polimorfonuclearelor în timpul inflamaţiei;

- supraîncărcarea cu fier şi peroxidarea lipidică;

- activarea NAD(P)H oxidazei de către proteina NS3;

- creşterea producției mitocondriale de SRO/ SRN prin lanțul de transport electronic legat de proteinele NS5A şi proteinelor core;

- scăderea producției de GSH din cauza leziunilor hepatice;

- scăderea antioxidanților şi a expresiei genelor acestora;

- alcoolul, drogurile şi alte toxice;

- creşterea citokinelor care augmentează SRO;

- creșterea expresiei CYP2E1;

- creşterea expresiei/activității Cox-2. 


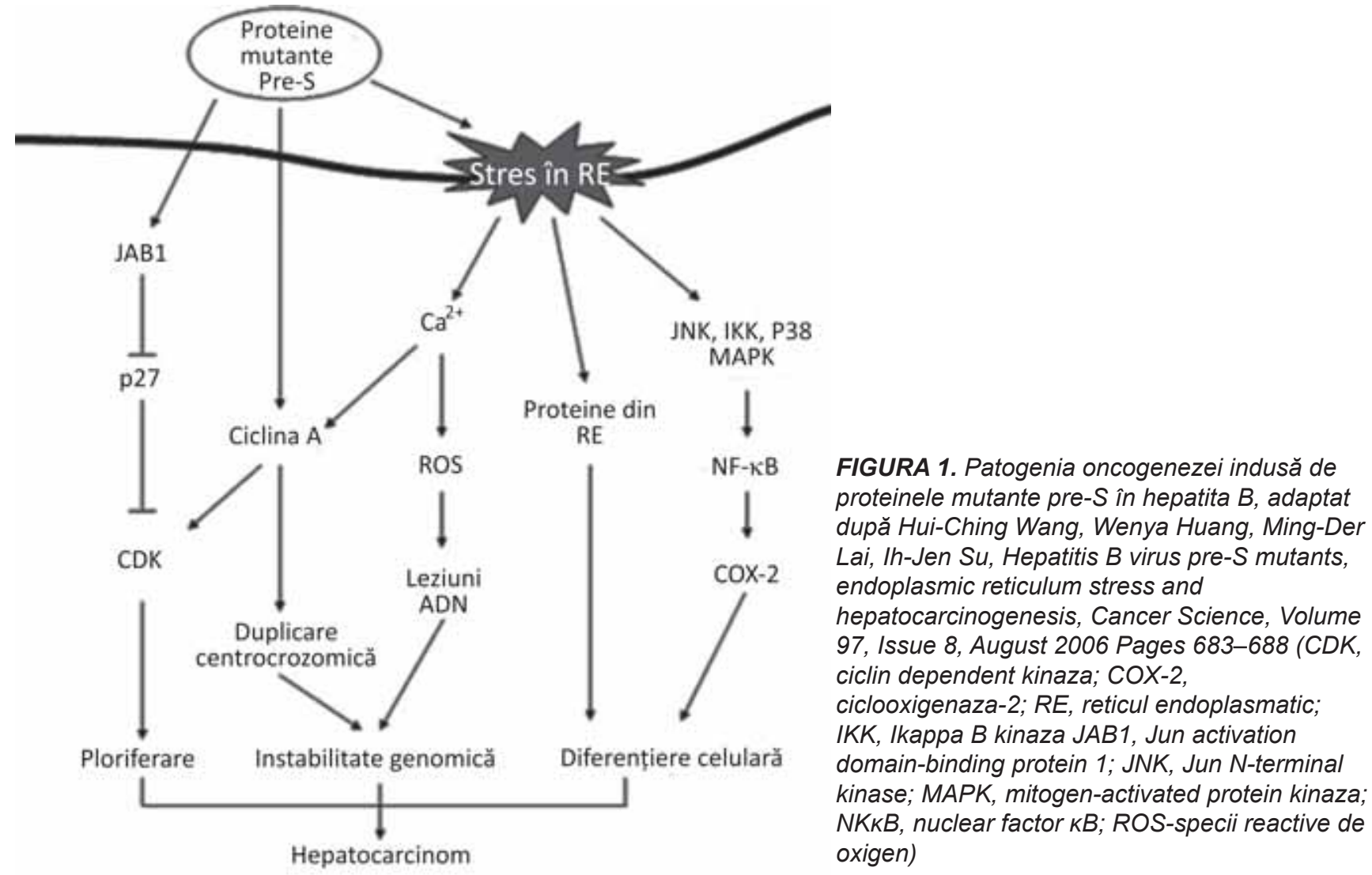

Existența unor depozite de fier, mai bine reprezentate în infecția VHC, facilitează stresul oxidativ, agravând rezistența la tratament. Fierul serveşte ca substrat în activarea stresului oxidativ la nivelul leziunii hepatice.

Pe de altă parte, studiile arată că VHC poate induce direct stres oxidativ în hepatocite. Expresia genelor core ale VHC a fost asociată cu creşterea SRO, scăderea intracelulară şi/sau mitocondrială a conținutului de GSH şi creşterea nivelului tioredoxinei oxidate şi a produşilor peroxidării lipidice.

Infecția cronică C progresează în mod frecvent spre ciroză, insuficiență hepatică sau hepatocarcinom. Pentru a elucida rolul stresului oxidativ în evoluția nefavorabilă a acestor pacienți, s-au evaluat nivelele sangvine şi/sau urinare ale markerilor de peroxidare a lipidelor, precum şi seleniul, vitaminele A,C,E într-un lot de 42 de pacienți cu hepatită C cronică. De asemenea, autorii au evaluat şi gradul fibrozei hepatice la un subgrup de 33 de pacienți. (6)

Rezultatele au arătat că markerii peroxidării lipidice (în principal 8-isoprostane) au fost crescuți în plasma pacienților, iar nivelul de glutation redus mitocondrial şi celular a scăzut semnificativ la aceştia. Antioxidanţii (glutationul, seleniul şi vitaminele A, C şi E) au înregistrat scăderi comparativ cu vârsta şi sexul subiecților din lotul martor. Valo- rile au fost mult mai scăzute în cazul subiecților cirotici, însă modificări semnificative au fost observate, de asemenea, şi în grupul de non-cirotici. Scorul de fibroză s-a corelat pozitiv cu valorile urinare d 8-isoprostane şi în mod negativ cu nivelul vitaminei A. În concluzie, după cum se reflectă în rezultatele obținute mai sus, stresul oxidativ este o caracteristică importantă a infecției cu virusul hepatitei C. Cu toate că scăderile produşilor antioxidanţi au fost marcate mai sever în grupul pacienților cirotici, există dovezi clare ale influenței stresului oxidativ şi la pacienții non-cirotici (6). Prin urmare, terapia antioxidantă poate avea un rol crucial în încetinirea progresiei bolii spre ciroză sau degenerescență malignă.

Dovezi indirecte sugerează că stresul oxidativ, asociat prejudiciului adus mitocondriei, are un rol important în evoluția nefavorabilă a infecției cu virus C. Unele studii au încercat să determine dacă proteina core VHC alterează funcția mitocondrială, contribuind astfel la iniţierea şi întreținerea stresului oxidativ (7). Astfel, au fost cuantificate proteina core VHC, exprimată în 3 linii celulare diferite, precum şi speciile reactive de oxigen (ROS) şi produşii de peroxidare a lipidelor. În 2 sisteme de expresie inductibile, nivelul proteinei core a crescut; de asemenea, produşii de peroxidare a lipidelor şi expresia genelor antioxidante au înregistrat creşteri 
semnificative. O secvență din proteina core exprimată la nivel mitocondrial a fost asociată cu redistribuția citocromului $\mathrm{C}$ din citosol, dovedind astfel încă o dată instalarea leziunilor dependente de stresul oxidativ la acest nivel. Sensibilitatea la stres oxidativ a fost observată la şoareci transgenici infectaţi cu VHC la care s-au înregistrat creşteri ale produşilor de peroxidare lipidică intrahepatici, ca răspuns la acțiunea tetraclorurii de carbon. Concluziile studiului au vizat prejudiciul oxidativ, care apare ca rezultat direct al expresiei proteinei core VHC atât in vitro, cât şi in vivo şi poate exercita un efect direct citopatic asupra mitocondriilor. Aceste rezultate oferă o perspectivă nouă în patogeneza hepatitei C, furnizând un raționament experimental pentru investigarea terapiei antioxidante ca linie terapeutică adjuvantă la aceşti pacienți.

Infecția cronică cu VHC este carcinogenetică (nu numai la nivel hepatic, dar şi la nivel de țesut limfoid), efect corelat cu scăderea activităţii GST, dovedind rolul important al acestuia în determinarea efectelor citopatice ale VHC. Mai mult, s-au decelat creşteri ale nivelului malonil-dialdehidei în serul pacienților cu hepatocarcinom, sugerând drept marker fidel al leziunii hepatice cuantificarea alfa-GST, acesta găsindu-se în concentrații mari în interiorul hepatocitelor. Nivelul alfa-GST creşte rapid în sânge la momentul producerii leziunilor şi scade la fel de rapid atunci când agresiunea încetează. Astfel, alfa-GST poate fi considerat cel mai sensibil marker al răspunsului la terapia antivirală. De asemenea, administrarea $\mathrm{N}$-acetil-cisteinei concomitent cu interferon duce la răspuns susținut în cazul pacienților cu hepatocarcinom rezistent la tratamentul cu interferon. $(8,9)$

Aceste afirmații sunt susținute de studiul efectuat de către Görenek L et al (2006), pe un lot de 19 pacienți cu infecție cronică cu VHC, respectiv un lot martor de 28 de indivizi sănătoşi. În ambele grupuri s-au dozat nivelele serice de alanin aminotransferază (ALT) şi aspartat aminotransferază (AST), precum şi nivelul de malondialdehidă (MDA), superoxid dismutază (SOD), precum şi de glutation peroxidază eritrocitară. Măsurătorile s-au efectuat înainte şi după tratamentul antiviral cu interferon alfa-2b şi ribavirină, timp de 48 de săptămâni (10).

Nivelurile serice ale MDA au crescut semnificativ la pacienții cu HCV cronică înainte de tratament, în comparaţie cu subiecții sănătoşi. De asemenea, concentraţia de MDA a scăzut semnificativ după tratament, ca şi valorile ALT, AST în grupul acestor pacienți. Enzime antioxidante (superoxid dismutaza şi glutation peroxidaza) au avut nivele semnificativ mai mici în eritrocitele pacienților cu hepatită cronică C înainte de tratament, comparativ cu grupul de control. În concluzie, rezultatele arată că pacienții cu infecție cronică cu VHC sunt sub influența stresului oxidativ, acțiunea acestuia fiind asociat cu niveluri mai scăzute ale enzimelor antioxidante. Deşi interferonul şi ribavirina, ca agenţi antivirali, nu au capacitate antioxidantă, prin acțiunea lor de reducere a replicării virale ar putea reduce şi inflamaţia şi, probabil, prin acest mecanism, ar putea scădea şi intensitatea stresului oxidativ indus de virus.

Aşadar, reducerea stresului oxidativ se poate face utilizând medicația antioxidantă (hepatoprotectoarele, acidul ursodeoxicolic şi vitamina E), acest demers reprezentând un beneficiu important pentru pacient.

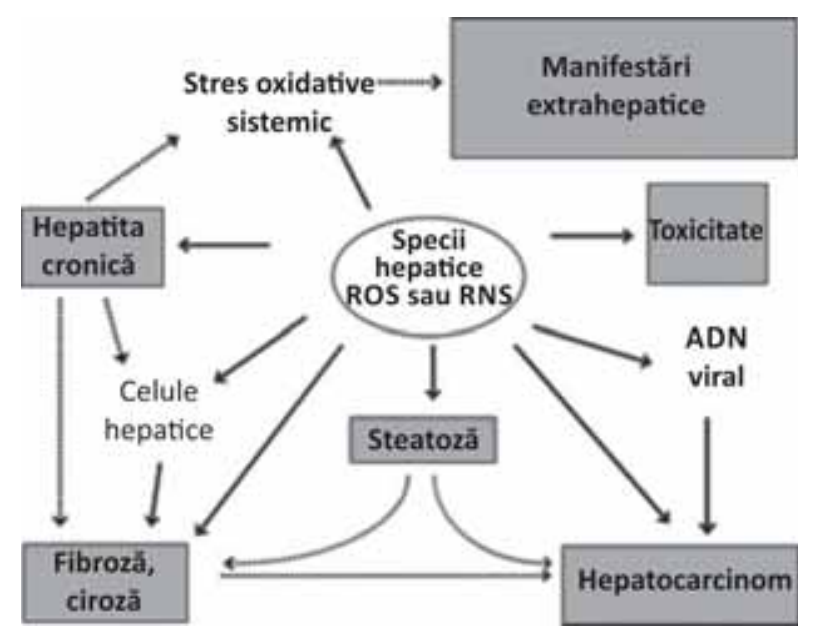

FIGURA 2. Efectele biologice ale speciilor reactive de oxigen/nitrogen în HVC (adaptat după Choi, J, Ou JHJ, Mechanisms of Liver Injury. III. Oxidative stress in the pathogenesis of hepatitis C virus, Am J of Phys, May 2006, 290(5), 847-851)

Prezența stresului oxidativ este semnalată şi prin valori serice crescute ale malondialdehidei MDA (marker pro-oxidativ), concomitent cu valori serice semnificativ scăzute ale glutationului redus (antioxidant endogen puternic), atât în hepatita cronică virală $\mathrm{C}$ cu manifestări extrahepatice la adulți, cât şi în hepatita cronică virală B la pacienții pediatrici. Există, de asemenea, o corelație directă între valorile serice ale MDA, GSH şi cele ale transaminazelor doar în hepatita acută virală C. Spre deosebire de faza acută, în infecția cronică doar valoarea MDA se corelează cu valorile transaminazelor. Aceste aspecte sugerează faptul că nivelurile serice ale MDA şi GSH nu sunt în strânsă interdependenţă cu gradul de necroză hepatocelulară. (11) Nu s-a obţinut corelație între ARN-VHC şi valorile serice ale MDA şi GSH nici în hepatita acută, şi nici în 
hepatita cronică virală C, ceea ce înseamnă că nivelul viremiei nu reflectă cu fidelitate intensitatea stresului oxidativ în sânge, fiind mai degrabă în strânsă interdependență cu valorile tisulare ale MDA, respectiv GSH.

Datele de laborator au arătat că tipul 0 al GSTM1 poate fi corelat cu evoluția mai severă a infecției cu VHC, cu o valoare predictivă pozitivă pentru cronicizare de $80 \%$. Determinarea antigenelor HLA incriminate în cronicizarea infecției VHC la pacienții cu tipul 0 de GSTM1, cunoscut fiind rolul unora dintre ele în evoluția severă a infecției VHC, precum şi în potențarea manifestărilor extrahepatice sunt un marker important de urmărit la acești pacienți. $(11,12)$

De asemenea, parametrii stresului oxidativ prezintă valori semnificativ mai alterate la pacienții pediatrici cu hepatită cronică virală $\mathrm{C}$ versus cei cu hepatită virală $\mathrm{B}$. Cu toate că interferonul şi ribavirina nu sunt agenți antioxidanți, prin capacitatea lor de a inhiba multiplicarea virală reduc inflamația şi, implicit, evoluția spre fibroză hepatică, ameliorând stresul oxidativ. Rezultatele favorabile obţinute în urma tratamentului antiviral, cu toate că nivelul viremiei a fost mare, se datorează, cel mai probabil, vârstei tinere a pacienților şi evoluției relativ recente a hepatitei.

Prezența manifestărilor extrahepatice nu modifică nivelul markerilor de stres oxidativ. Predominanța tipului 0 GSTM1 este demonstrată în procente relativ egale atât la pacienții cu infecție cronică VHC fără manifestări extrahepatice, cât şi la cei care asociază aceste manifestări, neputându-se asocia apariția manifestărilor extrahepatice cu stresul oxidativ. (11) Aşadar, malondialdehida serică, glutationul seric redus şi glutation S transferază pot fi utilizate ca biomarkeri ai severității și evoluției infecției cu virusul hepatitic C.

Studiile recente care au vizat patogenia infecțiilor hepatitice au dovedit că producția în exces a speciilor reactive de oxigen (SRO) este implicată mai ales în patogeneza hepatitei C. (15) S-a evaluat astfel statusul plasmatic antioxidant al pacienților infectați cu VHC, atât al celor care au beneficiat de terapia standard, cât şi al celor fără tratament antiviral. Măsurătorile s-au efectuat înainte şi după su- plimentarea cu vitaminele $\mathrm{E}, \mathrm{C}$ şi zinc (agenți antioxidanți). Biomarkerii stresului oxidativ au fost evaluați în cadrul a trei grupe de pacienți: lotul 1 control; lotul 2 - pacienți cu VHC, fără tratament, dozate înainte şi după suplimentarea zilnică a agenților antioxidanți (vitamina E $800 \mathrm{mg}$, vitamina C $500 \mathrm{mg}$ şi zinc $40 \mathrm{mg}$ ) timp de 6 luni; şi lotul 3 pacienți cu VHC tratați cu interferon pegylat asociat cu ribavirină. Aceşti pacienți din grupa 3 au fost investigați, de asemenea, înainte şi după aceeaşi terapie antioxidantă. Înainte de tratamentul antiviral cu interferon şi ribavirină, pacienții cu VHC au prezentat valori mari ale superoxid dismutazei, activitățile superoxid catalazei şi glutation peroxidazei fiind ridicate, şi scăderea activităţii glutation reductazei, în timp ce produşii lipoperoxidării a fost crescuți şi glutationul cu nivel mai scăzut în comparație cu grupul de control. Tratamentul cu terapia standard a intensificat activităţile catalazei şi glutation S-transferazei, a crescut conținutul de proteine de tip carbonil, ducând în final la epuizarea cantităților de glutation. După suplimentarea cu agenți antioxidanți s-a produs scăderea activităților catalazei şi glutation S-transferazei, a scăzut lipoperoxidarea la pacienții incluşi în lotul 2. În acelaşi timp, înainte de suplimentarea antioxidanților, AST şi ALT, precum şi GGT au prezentat creşteri semnificative la aceiaşi pacienți din lotul 2. Rezultatele au arătat ca pacienții cu $\mathrm{VHC}$, fie că primesc sau nu terapie standard antivirală, prezintă risc de a dezvolta leziuni ireversibile cu progresie spre ciroză şi/ sau hepatocarcinom, în condițiile stresului oxidativ indus de virus. Suplimentarea cu agenți antioxidanți conferă o protecție eficientă pentru ambele grupuri, prin atenuarea proceselor de oxidare legate de boală.

În concluzie, atât infecția cronică hepatitică cu virus $B$, cât şi cea cu virus $C$ implică suferință tisulară prin stres oxidativ direct la nivel hepatocitar. Tracking-ul patogenic urmează mecanisme diferite de acțiune, care în final conduc la degenerescență malignă. Dovezile studiilor întreprinse impun dezvoltarea unor linii terapeutice în scopul reducerii stresului oxidativ, asociate tratamentului antiviral standard. 